\title{
Comparison of Debris Flow Characteristics Obtained by Using Video Materials and Modeling
}

\author{
Viktoriia Antonovna Kurovskaia, Dariia Pavlovna Sokolova, Andrey Alekseevich Ostashov, \\ Tatyana Alexandrovna Vinogradova
}

Saint-Petersburg State University, Saint-Petersburg, Russia

Email: viktoriiakurovskaia@gmail.com, dariia.sokolova@yandex.ru, andrey.ostashov@gmail.com,vinograd1950@mail.ru

How to cite this paper: Kurovskaia, V.A., Sokolova, D.P., Ostashov, A.A. and Vinogradova, T.A. (2019) Comparison of Debris Flow Characteristics Obtained by Using Video Materials and Modeling. Open Journal of Geology, 9, 75-88.

https://doi.org/10.4236/ojg.2019.92007

Received: December 21, 2018

Accepted: February 25, 2019

Published: February 28, 2019

Copyright (c) 2019 by author(s) and Scientific Research Publishing Inc. This work is licensed under the Creative Commons Attribution International License (CC BY 4.0).

http://creativecommons.org/licenses/by/4.0/

\begin{abstract}
Velocity of debris flow is one of the most important characteristics for the protective construction design. Since debris flows are rare events, and observations are conducted only on stations in Russia, Ukraine, Italy, Switzerland, USA, China, Japan and New Zealand, the velocity is calculated rather than measured. Nowadays, a large number of videos with passing debris flows have appeared on the Internet. Scientists can use such video materials to obtain qualitative and quantitative characteristics of the debris flow. Therefore, the aim of our research is an attempt to measure the debris flow velocity using video materials and compare the obtained results with the calculated values using various methods. The debris flow that came down in Firgen, Austria on August 4, 2012 was chosen as the object of our study. The video was carried out from several angles, so it was possible to select a section of the channel, through which we could measure the debris flows waves velocity. In addition, we calculated the velocities of waves by formulas adopted in the regulatory documents and compared with the measured by video values. During the video analysis, debris flow velocities at different sites were observed: minimum $-7.2 \mathrm{~m} / \mathrm{s}$ and maximum $-10 \mathrm{~m} / \mathrm{s}$. The calculated values varied from 4.5 $\mathrm{m} / \mathrm{s}$ to $11.4 \mathrm{~m} / \mathrm{s}$. Moreover, we applied model of the transport-shear process of debris flow formation developed by Yu. B. Vinogradov. When we were comparing the obtained debris flow discharges with results from Austrian colleagues, we found out that the values were similar to each other. However, internal scatter in the model changed from 151 to $190 \mathrm{~m}^{3} / \mathrm{s}$, while in the report of Austrian colleagues the discharges were from 80 to $250 \mathrm{~m}^{3} / \mathrm{s}$.
\end{abstract}

\section{Keywords}

Debris Flow, Velocity of Debris Flow, Video Material of Debris Flow, Empirical Formulas, Modeling 


\section{Introduction}

One of the most important issues that appears during the study and modeling of debris flow processes (in both scientific research and surveying) is the question of the debris flow velocity. In our research, the debris flow velocity is the wave ridge velocity. This value is the necessary characteristic in the design of protective structures.

Data from direct measurement of debris flow velocity obtained during its movement are insufficient [1]. Direct measurement of debris flows characteristics is associated with many difficulties; the main one is determined by the rarity of this hazard.

Applying video materials to define dynamic characteristics of the flow has proved to be a reliable method for obtaining field data of this dangerous event. Debris flow velocity was defined from the video in the north of Italy [2] [3] [4]. Video cameras for determining the dynamic characteristics of mudflows were also used in China [5]. In Russia, such studies were also carried out, for example, employees of the Far Eastern Geological Institute of the Far East Branch of the Russian Academy of Sciences on a tributary of the Khomutovka River installed a photo trap, where anthropogenic mudflows were observed.

Values of flow velocity obtained in the field studies, which were conducted after the event, were giving unreliable results, since the methods were based mostly on mathematical models with empirical coefficients.

The possible solution to this problem is to use a large number of field observations of the flows and to measure their velocity during movement.

However, nowadays many video materials have appeared on the Internet, which capture various flows passing. These materials can be used to calculate qualitative and quantitative characteristics of the debris flows, such as the structure rheological type, the flow pattern, the form of the debris flow waves and their velocity in different parts of the channel.

Flow velocity assessment by a video as a method for studying this phenomenon has a number of limitations. Firstly, debris flows often occur in uninhabited or underpopulated areas; there is no possibility to register debris flow waves from the early start until the end. Secondly, during the development of the phenomenon, precipitation of high intensity often occurs, which prevents the event recording. Thirdly, the shooting angle and lighting conditions are the factors that affect the quality of the footage and, therefore, the measurement accuracy. The last but not the least, limitation is the geographic position, which is necessary for finding the course distance and morphometric characteristics using satellite images. If there are the objects in the frame that can be used for geo-referencing, we can estimate discharge by determining the cross-sectional area of the stream. Under all conditions, it is possible to obtain the maximum debris flow velocity with a sufficient degree of reliability.

The aim of our research was to make an attempt of measuring the debris flow velocity based on the video materials and compare them with the calculated val- 
ues using various methods.

\section{Overview of Study Area}

Eastern Alps are characterized by special geographical, geological and hydrological conditions that define debris flow possibility of formation and the frequency with large volumes.

Precipitation intensity reaches world peaks of $600-670 \mathrm{~mm}$ during two and half an hour. Along northern and eastern ridge maximum values of daily precipitation are $200-250 \mathrm{~mm}$ [6].

The amount of loose material fan after catastrophic debris flows reaches up from hundreds of thousands to a million $\mathrm{m}^{3}$ [6] (Figure 1). Since the population density in Alps is very high, catastrophic flows are equivalent to national disasters [7]. The first announcement about debris flows in Austria dates to 600, when the flow descended from the Lanbach Gorge to the Inna Valley near the village of Schwaz.

On 4 August 2012 debris flow occurred along the Firshnitzbach stream. As a result, the town of Firgen suffered, infrastructure and residential buildings were damaged. The flow was filmed on video cameras from several angles by local residents and authorities, which allowed us to determine some of the qualitative and quantitative characteristics of the debris flow.

The Firshnitzbach stream (Figure 2) is the left-bank tributary of the Isel River in the municipality of Firgen. The catchment area is $4.1 \mathrm{~km}^{2}$, the length of the Firshnitzbah stream is $5.5 \mathrm{~km}$; the elevation difference from the source to the mouth is $1955 \mathrm{~m}$ [10].

The study watershed is located on the territory of Pennine Alps. The phylliticshales, which have a high content of clay particles that can bind water in the subsoil (in our opinion, a necessary condition for the formation of viscous stream), as well as the presence of loose material and scree material in the upper part of the catchment, can form potential mudflow mass in this region. Lime-mica schists, metabasites, and ultrabasic rocks [10], which saturate the flow with large detrital rocks, represent the bedding rock.

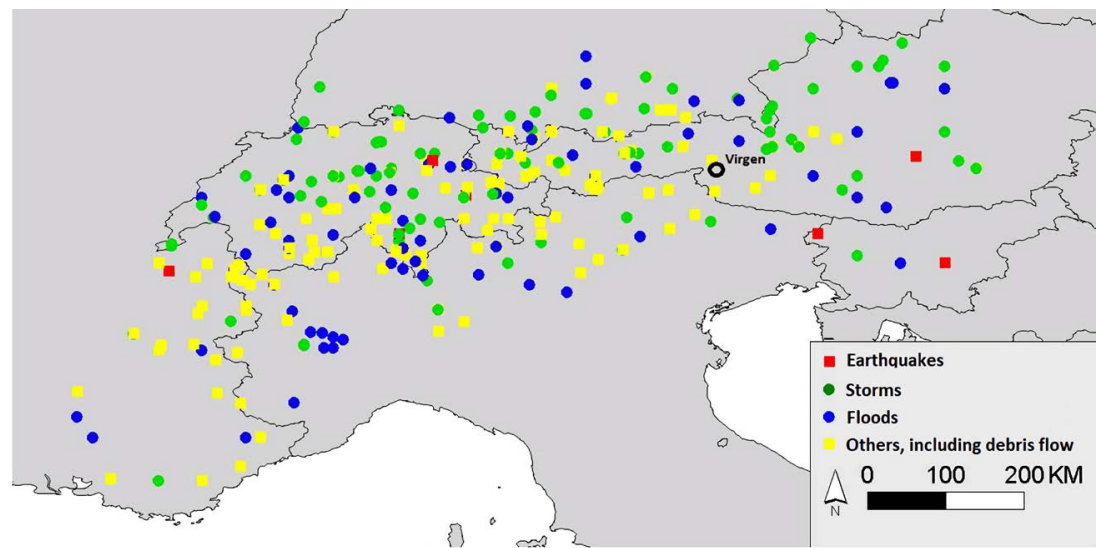

Figure 1. Disasters and Loss Events in the Alps, 1980-2005 [8] [9]. 


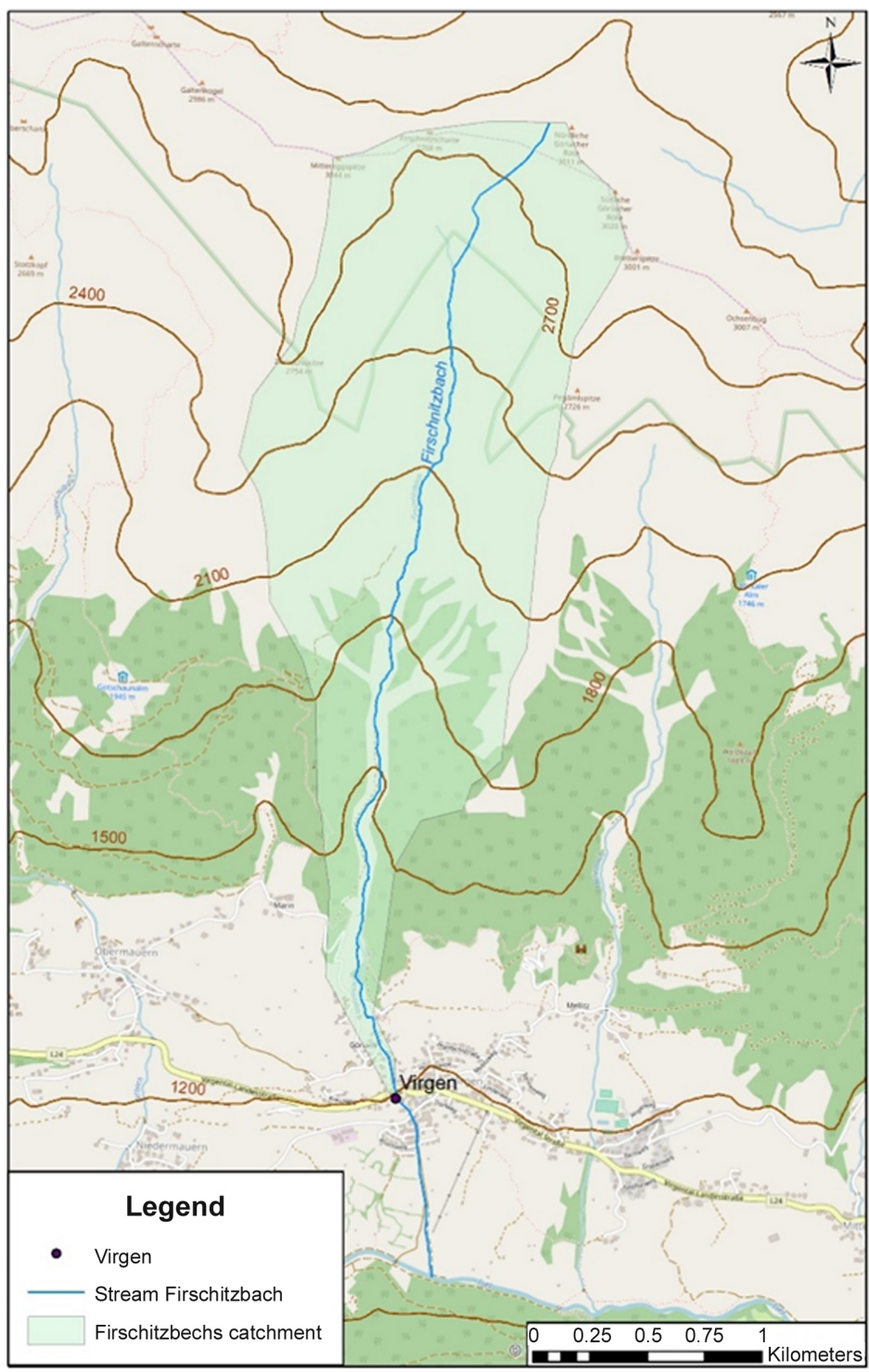

Figure 2. The scheme of basin Firschnitzbach River.

About a quarter of the study area is occupied by coniferous forest, $27 \%$ includes meadow pasture land and alpine meadows, $38 \%$ is non-sodded loose material. The remaining $10 \%$ is the building systems [10].

Several debris flow protection structures are situated in the Firshnitzbach stream watershed (Figure 3). Check dam is in $1830 \mathrm{~m}$ from the mouth and designed to storage $25,000 \mathrm{~m}^{3}$ of loose material. Below the damn, debris flow check canal is located, which is designed for debris flow with the discharge of $60 \mathrm{~m}^{3} / \mathrm{s}$ [10].

Heavy downpour with an intensity of $2 \mathrm{~mm} / \mathrm{min}$ preceded the studied debris flow. Duration of the first downpour was thirty minutes. On August 4, 2012, at 15:25 local time, residents of Firgen observed the first wave of debris flow 15 minutes after the rain had started. In just 40 minutes, twelve waves were recorded. By the time of first wave formation, $30 \mathrm{~mm}$ of precipitation managed to 


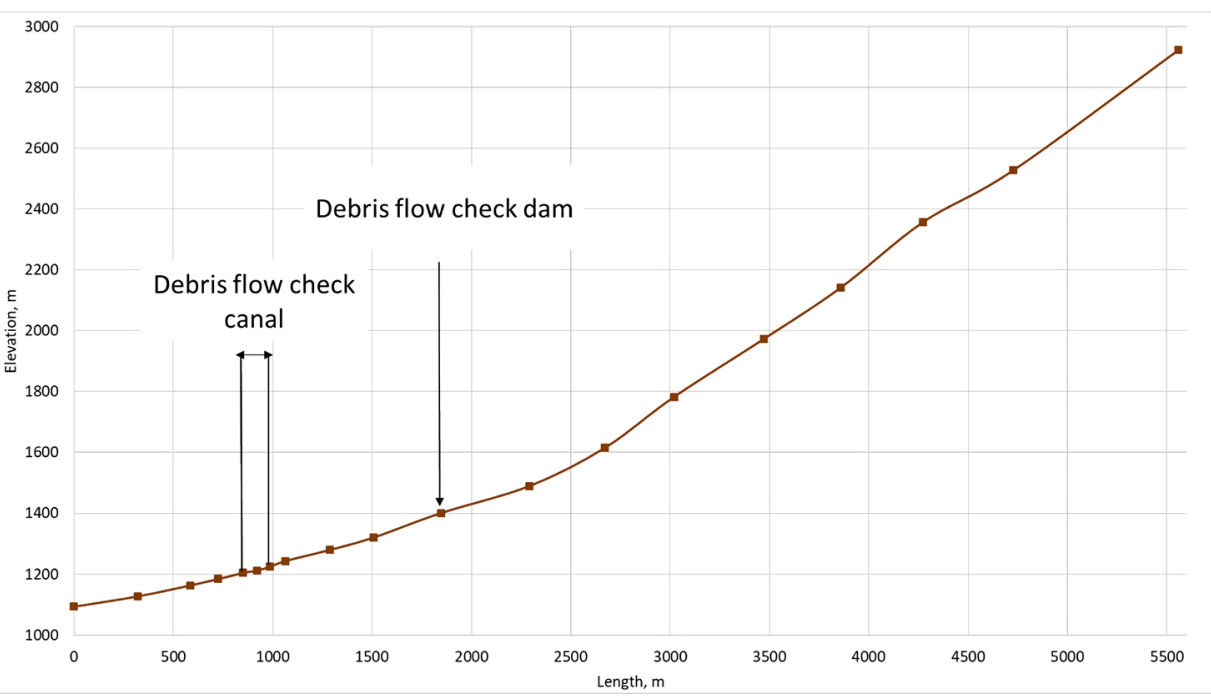

Figure 3. The longitudinal profile of the Firschnitzbach stream.

fell. The second stage included 27 debris flow waves within 50 minutes with the same rain intensity for 45 minutes. By the time the second stage of the debris flow began, the dam was overflowing, and the stream went over the dam crest. In total, for the period of two series of debris flow waves, according to the data of Hjublja Y. et al., 70,000 $\mathrm{m}^{3}$ of material was carried out [10].

Dynamic characteristics of the flow were higher than designed value of Firgen protection structures. The check dam was filled with deposits after the first series of waves. Debris flow check canal was not able to omit maximum flow discharges; therefore the debris flow overflowed the banks of the channel and spread out on the sidewalks.

\section{Methodology}

The video was provided by Josef Fibiger (Consultant in erosion, Torrent and Avalanche Control \& Forestry; IUFRO Research Group 8.03 Natural Disasters, Salzburg, Austria) at the 4th international conference "Debris flows: disasters, risk, forecast, protection” (Irkutsk-Arshan, September 6-10, 2016). The survey was carried out by local residents and authorities from different points of the city, where the debris flow moved along a concreted stepped mudflow check canal.

Authors with the help of the ArcGIS program and map controlling made the longitudinal profile of the Firschnitzbach stream.

We have chosen the frames, where it was possible to determine the place in the satellite image where the flow took place. It is necessary to define distance and duration of debris flow movement in order to determine the flow velocity based on video materials.

To begin with, we controlled Firgen debris flow check canal in software package called ArcGIS. Map control was carried out on the channel control points in the satellite image (bridge, parking, stage on the corner) (Figure 4). 


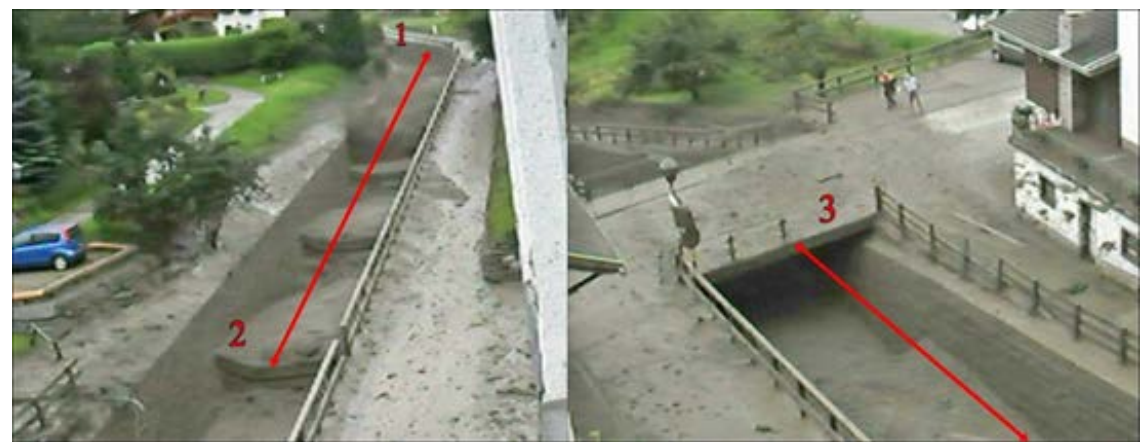

Figure 4. The scheme of the debris flow passage's sections: 1 -step on the turn; 2 -step in ridge of the parking; 3 -bridge.

We chose three sections, where the movement of the debris flow wave ridge was clearly visible on the video.

The first one, on which the maximum number of waves was recorded from parking (2) to the bridge (3). The second section starts from the step at the channel turn (1) to the bridge (3). The third section: from the turn (1) to the parking (2) (Figure 4).

The flow depth was defined by control of scale compared with various objects. For example, man, car, etc. were used. In the ArcGIS program, the necessary measurements of the channel length and width were conducted for further calculations (Table 1).

The velocity determination was carried out as follows. In the software package Shortcut time of debris flow wave ridge movement was recorded at the control points, which corresponded to the steps in the channel. The velocity was calculated as the distance divided by the time.

In this research, velocities of passing debris flow in Firgen were calculated by various methods. We applied formulas of I. I. Herheulidze, V. V. Golubcov, M. F. Sribnyj and Kkhann, Academy of the State Fire Service Emergencies Ministry of Russia [11]. Guide of debris flow stations and hydrographic parties recommends using the following equation:

$$
v_{c}=4.83 h^{0,5}(\sin \alpha)^{0,25}
$$

where $h$-average flow depth, m; $a$-average angle of slope of the mudflow bed, nondimensional. Formula was proposed by Kherkheulidze [12].

In addition, M. F. Sribnyj formula [13] is often used, which in expanded form will be written as:

$$
v_{c}=\frac{6.5 R^{3 / 4} I^{1 / 4}}{\sqrt{\frac{\gamma_{c} \gamma_{m-} \gamma_{m}}{\gamma_{m}-\gamma_{c}}}+1}
$$

where $R$-area border ratio $\mathrm{m}, I$-slope of the mudflow bed, nondimensional, $\gamma_{m}$-sediment density, $\mathrm{kg} / \mathrm{m}^{3}, \quad \gamma_{c}$-average debris flow density, $\mathrm{kg} / \mathrm{m}^{3}$.

Accepting the assumption that volumes of debris flow's solid and liquid components are equal, the M. F. Sribnyj Formula changes to: 
Table 1. The main parameters of the channel.

\begin{tabular}{|c|c|c|c|c|c|c|}
\hline & Section & & & & & \\
\hline Number & $\begin{array}{l}\text { Address, } m \text { from the } \\
\text { Firshnitzbach stream mouth }\end{array}$ & $\begin{array}{l}\text { Width of the } \\
\text { channel, } m\end{array}$ & $\begin{array}{l}\text { Depth of the } \\
\text { channel, } \mathrm{m}\end{array}$ & $\begin{array}{l}\text { Length of the } \\
\text { stage, } m\end{array}$ & $\begin{array}{l}\text { Slope, } \\
\text { degrees }\end{array}$ & $\begin{array}{l}\text { Number } \\
\text { of waves }\end{array}$ \\
\hline 1 & $920-850$ & 5.8 & 3.0 & 14.3 & 10.6 & 10 \\
\hline 2 & $985-850$ & 5.8 & 3.0 & 14.3 & 10.2 & 3 \\
\hline 3 & $985-920$ & 5.8 & 3.0 & 14.3 & 9.8 & 3 \\
\hline
\end{tabular}

$$
v_{c}=4.25 R^{3 / 4} I^{1 / 4}
$$

Also, to determine the debris flow velocity the Kkhann Formula is used [13]:

$$
v_{c}=8.05 h^{0,58} i^{0,30}
$$

where $h$-the average flow depth, $\mathrm{m} ; i$-slope of the mudflow bed, nondimensional.

According to the educational and methodological manual issued by the Academy of the State Fire Service of the Ministry of Emergency Situations of Russia [11], the velocity of debris flow movement can be determined by the formula:

$$
v_{c}=11.4 h^{0,5}\left(U \sin \alpha^{\frac{1}{3}}\right)
$$

where $U$ is the relative fall diameter of loose materials involved in the flow (for operational calculations it is assumed to be 0.7 ... 1.0);

Also, V. V. Golubcov [12] proposed formulas for calculating mud and debris flows:

$$
v_{c}=3.75 h^{0,5} i^{0,17}
$$

\section{Results}

Wave ridge velocities varied from 7.4 to $10 \mathrm{~m} / \mathrm{s}$ within the video shooting. According to the results, it is obvious that the velocity relates to the flow depth. For instance, velocity of wave № 3 with depth of $3.4 \mathrm{~m}$ was $10 \mathrm{~m} / \mathrm{s}$, while for wave № 2 with depth of $2 \mathrm{~m}$ this value was $7.4 \mathrm{~m} / \mathrm{s}$. Three waves (№ 4, 5, 7) were defined on three sections. Velocities of this waves differed from $0.3 \mathrm{~m} / \mathrm{s}$ to $0.8 \mathrm{~m} / \mathrm{s}$, which indicates the variability of the debris flow movement.

Employees of the Austrian Institute of Mountain Hazards determined the flow velocity using video materials in the channel section $(530 \mathrm{~m}$ from the mouth of the Firshnitzbach stream), the values range from 4 to $10 \mathrm{~m} / \mathrm{s}$ [10]. To estimate the debris flow velocity, the Austrian colleagues used the same video materials that were applied in this research.

The calculations results at the three sections using various methods described in the chapter "materials and methods" are provided in Table 2 and Figure 5.

The calculation results of the debris flow velocity based on various methods 
Table 2. Velocity of debris flow, calculated according to different methods.

\begin{tabular}{|c|c|c|c|c|c|c|c|c|c|}
\hline \multicolumn{4}{|c|}{ Data } & \multicolumn{6}{|c|}{ Velocity, m/s } \\
\hline $\begin{array}{l}\text { Address, } \mathrm{m} \text { from } \\
\text { the Firshnitzbach } \\
\text { stream mouth }\end{array}$ & $\begin{array}{l}\text { № of } \\
\text { wave }\end{array}$ & Depth, m & Slope, ${ }^{\circ}$ & $\begin{array}{l}\text { Herheulidze } \\
\text { I. I. }\end{array}$ & $\begin{array}{c}\text { Academy of the State Fire } \\
\text { Service of the Ministry of } \\
\text { Emergency Situations of Russia }\end{array}$ & Golubcov & V. V.Sribnyj M. F. & Kkhann & $\begin{array}{l}\text { Velocity of } \\
\text { the ridge } \\
\text { (by video) }\end{array}$ \\
\hline \multirow{10}{*}{$920-850 \mathrm{~m}$} & 1 & 2.7 & 10.6 & 5.2 & 10.2 & 4.6 & 5.4 & 8.7 & 8.1 \\
\hline & 2 & 2.7 & 10.6 & 5.2 & 10.2 & 4.6 & 5.4 & 8.7 & 7.2 \\
\hline & 3 & 3.4 & 10.6 & 5.9 & 11.4 & 5.2 & 6.3 & 9.9 & 10.0 \\
\hline & 4 & 2.5 & 10.6 & 5.0 & 9.8 & 4.5 & 5.2 & 8.3 & 8.1 \\
\hline & 5 & 2.9 & 10.6 & 5.4 & 10.5 & 4.8 & 5.7 & 9.0 & 8.8 \\
\hline & 6 & 3.0 & 10.6 & 5.5 & 10.7 & 4.9 & 5.8 & 9.2 & 9.3 \\
\hline & 7 & 3.2 & 10.6 & 5.7 & 11.1 & 5.0 & 6.1 & 9.6 & 9.8 \\
\hline & 8 & 3.4 & 10.6 & 5.9 & 11.4 & 5.2 & 6.3 & 9.9 & 9.6 \\
\hline & 9 & 2.5 & 10.6 & 5.0 & 9.8 & 4.5 & 5.2 & 8.3 & 8.5 \\
\hline & 10 & 2.0 & 10.6 & 4.5 & 8.7 & 4.0 & 4.4 & 7.3 & 7.4 \\
\hline \multirow{3}{*}{$985-850 m$} & 4 & 2.5 & 10.2 & 5.0 & 9.7 & 4.4 & 5.1 & 8.2 & 7.9 \\
\hline & 5 & 2.9 & 10.2 & 5.4 & 10.4 & 4.8 & 5.6 & 8.9 & 8.4 \\
\hline & 7 & 3.2 & 10.2 & 5.6 & 10.9 & 5.0 & 6.0 & 9.5 & 9.5 \\
\hline \multirow{3}{*}{$985-920 \mathrm{~m}$} & 4 & 2.5 & 9.8 & 4.9 & 9.5 & 4.4 & 5.0 & 8.1 & 7.7 \\
\hline & 5 & 2.9 & 9.8 & 5.3 & 10.2 & 4.7 & 5.6 & 8.8 & 8.0 \\
\hline & 7 & 3.2 & 9.8 & 5.6 & 10.8 & 5.0 & 6.0 & 9.3 & 9.2 \\
\hline
\end{tabular}

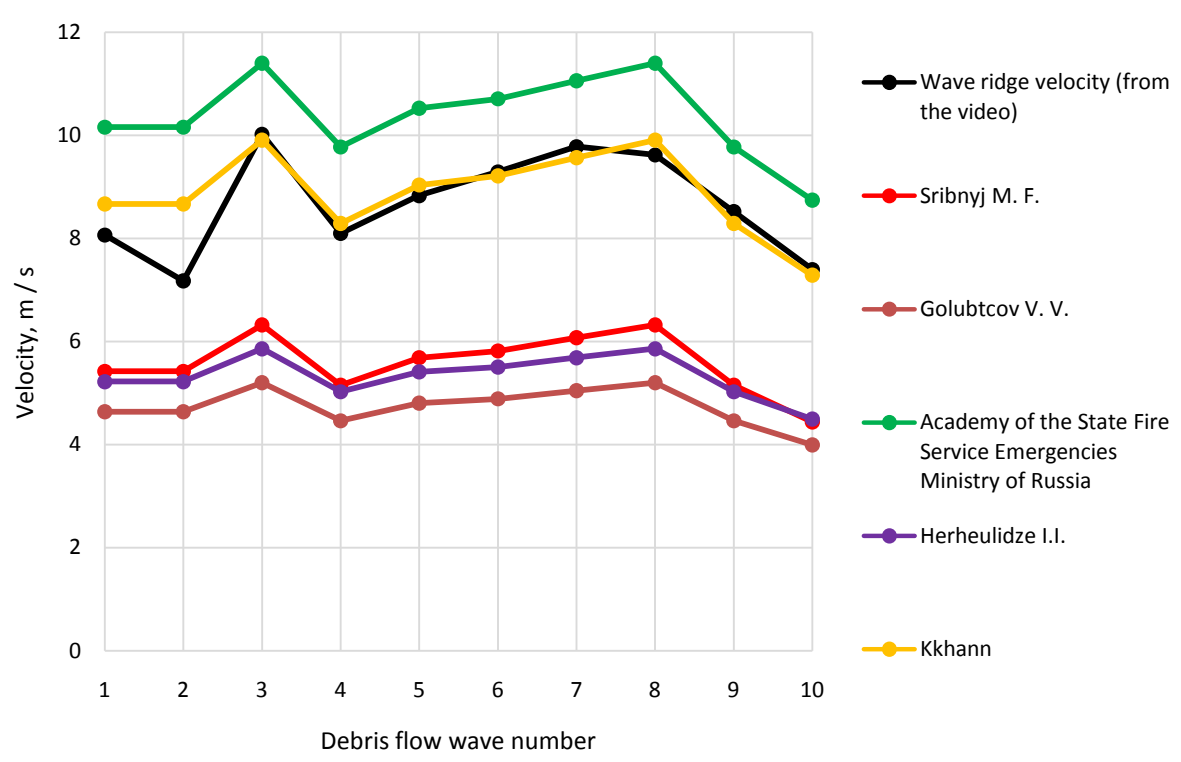

Figure 5. The velocity of the debris flow.

are rather different. All formulas used are derived empirically and mainly include such characteristics as flow depth and channel slope. All the coefficients in the formulas were based on field materials in different regions of the former 
USSR.

For example, Herheulidze I.I. and Golubcov V.V. deduced their formulas for calculating the movement velocity of the debris flow, based on the materials, which were obtained during their survey of the debris processes in Georgia and Kazakhstan, respectively.

The formula proposed by the Academy of State fire service of the Ministry of Emergency Situations of Russia provided the highest values of debris flow velocity $(8.7 \mathrm{~m} / \mathrm{s}-11.4 \mathrm{~m} / \mathrm{s})$. Using this formula for the determination of the protective structures' parameters will be impractical from the economic point of view.

Moreover, formulas developed by I. I. Kherkheulidze, V. V. Golubtsova and M. F. Sribnyj provided low values of debris flow velocity compared with those determined from the video, the amplitude is $2.5 \mathrm{~m} / \mathrm{s}-4.8 \mathrm{~m} / \mathrm{s}$. Applying these formulas underestimate the velocity of debris flow that can lead to the destruction of protection structures and to the flooding of the territories.

The figure above shows that velocities according to Kkhann formula are similar to results from the video material. However, because there is no available information on the theoretical description of this formula and principles on which the Kkhann formula is based, it is impossible to verify the assumptions about the reliability degree of the results.

In addition, empirical coefficients for the mentioned earlier formulas were developed in laboratories. Besides, these formulas are based only on two values: the channel slope and the flow depth. In our opinion, such methods do not include flow dynamic. Moreover, there is no standard method to estimate debris flows velocity for more correct designing of the defense structures.

Finally, for comparison the methods, experimental and specific observations of mudflows are necessary. Unfortunately, there are only a few materials around the world. The debris flow velocity by automatic sensors is determined at the debris flow stations [2] [3] [4] [5]. At the moment, to determine the quantitative characteristics of flows, Russian researchers often apply the formulas of I. I. Herheulidze and V.V. Golubcov [12] [14]. In fact, all empirical formulas provide an approximate description of the debris flow wave velocity.

\section{Mathematical Modeling}

To calculate the characteristics of the debris flow we applied the model of the transport-shift process, developed in Russia by Professor Yu. Vinogradov [15]. High-density debris flows occur as a result of the development of the transport-shift processes, which are the most frequent and dangerous ones. The mod$\mathrm{el}$ is based on the equations of the instability coefficient of the potential debris flow array, the flow elementary potential power and the mobility index of the debris flow mass. The model verification was carried out using measured data on experimental (in natural conditions) debris flows [1]. Artificial debris flow experiments were conducted in 1972-1976 years in the Chemolgan River, organized by the Kazakh research hydro-meteorological Institute. 
When constructing the model, the following concepts and provisions were used:

1) The instability coefficient of the PDFB as the reciprocal value of the well-known soil mechanics and engineering Geology coefficient of loose-fragmental debris mass slope stability. In this case the coefficient is determined for PDFB as:

$$
K=\frac{\operatorname{tg} \alpha}{\operatorname{tg} \varphi}
$$

2) Elementary potential flow capacity (ability to produce work per unit of track per time unity $\mathrm{W} / \mathrm{m}=\mathrm{kg} \times \mathrm{m} / \mathrm{s}^{3}$ ).

$$
U=g \times\left[Q \times \rho_{0}+\left(\zeta \times \rho_{0}+\rho\right) \times G\right] \times \sin \alpha
$$

3) The index of mudflow mass mobility

$$
R=\frac{Q}{G}+\zeta-\theta_{n n}
$$

here $Q / G$ is the ratio of water and solid rock substance runoffs in a mud-stone flow moving over the thalweg of a debris flow hotbed. $\zeta$-relative humidity of PDFB (the ratio of volumetric moisture content by volume fraction of solids in a potential debris flow body of a debris flow hotbed); $\theta_{n n}-$ the same ratio but at the limit of a mixture of water and rock fludity (in the first approximation is taken equal to 0.133). The formation and movement of debris flow is meant to stop when $R \leq 0$. In the mountains, you often can see "stalled debris flows", especially on extensive screes, where the amount of water involved in such developments is almost always limited. Let us assume the following situation: the flow rate increment of the solid material involved in an incipient mudflow, as it moves through the riverbed of debris flow hotbed, is directly proportional to the three arguments:

$d l d G=A \times K \times U \times R=A \times \frac{\operatorname{tg} \alpha}{\operatorname{tg} \varphi} \times g \times \sin \alpha \times\left[Q \rho_{0}+\left(\zeta \times \rho_{0}+\rho\right) \times G\right] \times\left(\frac{G}{Q}+\zeta-\theta_{n n}\right)$

where $A$-is the coefficient of proportionality $\left(\mathrm{m} \cdot \mathrm{s}^{2} / \mathrm{kg}\right) ; 1$-distance over a thalweg; $\alpha$-the angle of inclination of a debris flow hotbed bedplate containing the PDFB; $\varphi$ - the angle of internal friction of damp rock (static) composing the PDFB; $Q$ - water flow runoff into the debris flow hotbed $\left(\mathrm{m}^{3} / \mathrm{s}\right) ; G$ - solid substance (rocks) runoff in a debris flow $\left(\mathrm{m}^{3} / \mathrm{s}\right)$. After the necessary integration the following result is obtained [1]:

$$
\begin{aligned}
l= & {\left[Q \times \rho_{0} \times \zeta \times \rho_{0}+\rho \times \ln \left(Q \times \rho_{0}\right)+\left(\zeta \times \rho_{0}+\rho\right) \times G \times Q \times \rho_{0}+\left(\zeta \times \rho_{0}+\rho\right)\right.} \\
& \left.\times G_{0}-Q \times \zeta-\theta_{n n} \times \ln Q+\left(\zeta-\theta_{n n}\right) \times G \times Q+\left(\zeta-\theta_{n n}\right) \times G_{0}\right] \\
& \times \operatorname{arctg} \varphi \times g \times \sin \alpha \times\left[Q \times \rho_{0} \times\left(\zeta-\theta_{n n}\right)+Q \times\left(\zeta \times \rho_{0}+\rho\right)+l_{0}\right]
\end{aligned}
$$

The coefficient of proportionality was obtained by artificial experiment of debris flows. According to the experiment results, the coefficient of proportionality is in the range of $\mathrm{A}=(3 \div 5) \times 10^{-6} \mathrm{~m} \cdot \mathrm{s}^{2} / \mathrm{kg}[1]$.

The basic calculation equation is solved not relatively to the sought function 
$G$, but to the argument $l$, which causes some inconvenience. However, the equation primary solution is a basic computational procedure. As a result, we have a dependency $G$ on the track length of the forming debris flow during its progress through the thalweg of debris flow hotbed. The final step is to calculate the two most important parameters. The discharge of debris flow in the process of its movement in the debris flow original site:

$$
Q_{c}=Q+(1+\zeta) \times G
$$

The debris flow density in the process of its movement in the debris flow original site:

$$
\rho_{c}=\frac{\left(\rho_{0} \times Q+\left(\theta_{n n} \times \rho_{0}+\rho\right)\right) \times G}{\left(Q+\left(1+\theta_{n n}\right)\right) \times g}
$$

The thalweg was divided into 5 sections of equal length approximately $1.1 \mathrm{ki}$ lometers (Figure 6). Distance from the beginning of the thalweg to the mouth of the stream is 5.5 kilometers. The discharge of debris flow and density of debris flow was calculated at each section. The calculation results are shown in Table 3.

The largest discharge of debris flow is $190 \mathrm{~m}^{3} / \mathrm{s}$, the smallest is $151 \mathrm{~m}^{3} / \mathrm{s}$ and the density of debris flow mass ranges from 1995 to $1955 \mathrm{~kg} / \mathrm{m}^{3}$.

The debris flow discharges were calculated using the results of velocity measurements from video recording in the channel (Figure 6). Final results are presented in Table 4.

When we compared the obtained debris flow discharges with results of the Austrian colleagues, we found that the values are similar to each other. However, Austrian colleagues have a large scatter of debris flow discharges from 80 to 250 $\mathrm{m}^{3} / \mathrm{s}$. Unfortunately, there is no information of how the flow discharges were

\begin{tabular}{|c|c|c|c|c|c|}
\hline \multicolumn{2}{|r|}{ Thalweg } & \multirow[b]{2}{*}{ Slope, degree } & \multirow[b]{2}{*}{$\begin{array}{l}\text { The sediment } \\
\text { discharge, } \mathrm{m}^{3} / \mathrm{s}\end{array}$} & \multirow[b]{2}{*}{$\begin{array}{l}\text { The discharge of } \\
\text { debris flow, } \mathrm{m}^{3} / \mathrm{s}\end{array}$} & \multirow[b]{2}{*}{$\begin{array}{c}\text { Debris flow } \\
\text { density, } \mathrm{kg} / \mathrm{m}^{3}\end{array}$} \\
\hline No. & $\begin{array}{l}\text { Adress, } \mathrm{km} \text { from } \\
\text { the Firshnitzbach } \\
\text { stream mouth }\end{array}$ & & & & \\
\hline 1 & $5.5-4.4$ & 25.2 & 77.0 & 190 & 1995 \\
\hline 2 & $4.4-3.3$ & 23.4 & 76.5 & 188 & 1994 \\
\hline 3 & $3.3-2.2$ & 21.6 & 76.0 & 187 & 1993 \\
\hline 4 & $2.2-1.1$ & 11.7 & 68.0 & 169 & 1975 \\
\hline 5 & $1.1-0$ & 8.0 & 60.5 & 151 & 1955 \\
\hline
\end{tabular}

Table 3. Results of modeling.

Table 4. Comparative results.

\begin{tabular}{cc}
\hline Methods & The discharge of debris flow, $\mathrm{m}^{3} / \mathrm{s}$ \\
\hline Results of modeling & $151-190$ \\
Results of calculation by video & $85-196$ \\
Results from the Austrian report & $80-250$ \\
\hline
\end{tabular}




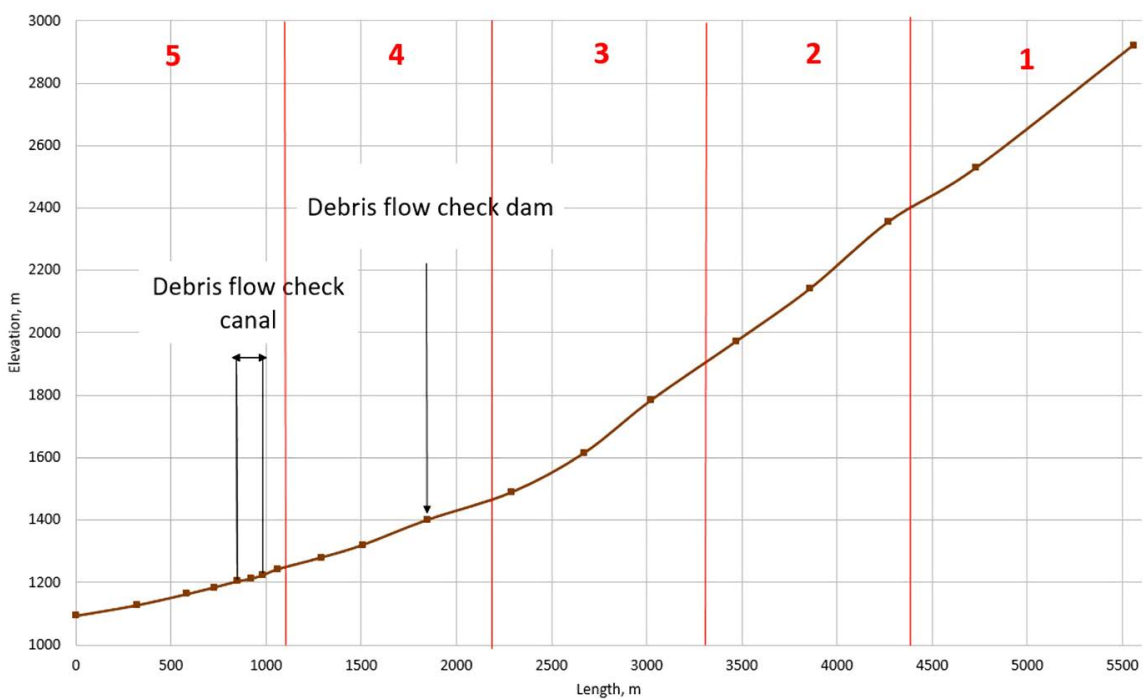

Figure 6. The longitudinal profile of the Firschnitzbach stream with 5 sections.

estimated in the Austrian colleagues report. The internal scatter in the model is from 151 to $190 \mathrm{~m}^{3} / \mathrm{s}$.

Using model of $\mathrm{Yu}$. B. Vinogradov, the following characteristics of the flow such as internal angle of friction, the density of the rock, etc. were taken into account. In this research maximum debris flow discharge and its density was calculated in various sections of the course. The difference between the modeled discharge and estimated by video materials on the particular section of the channel was $45 \mathrm{~m}^{3} / \mathrm{s}$. The model of the transport-shift process was verified in Kazakhstan for the Chemolgan watershed [1]. Besides, the characteristics of debris flows for the Transbaikalian region are being calculated. Since this model consists of flow dynamics mathematical equations, that were previously verified, we can conclude, that the model gives satisfactory results.

The method for determining the characteristics of the dangerous events from video materials is perhaps more accurate than empirical methods, since the parameters are defined during the movement of the debris flow. When determining the hydraulic-morphometric characteristics of the channel, the parameters may be refined.

\section{Conclusions}

Video material describing debris flow of 4.08.2012 in Firshnitzbach stream allowed to:

- Measure the flow velocity, which in different areas of the channel varied from $7.2 \mathrm{~m} / \mathrm{s}$ to $10.0 \mathrm{~m} / \mathrm{s}$;

- Clearly define 10 debris flow waves.

Analysis of available formulas for determining debris flows velocity established that maximum values were obtained by the Academy of the State Fire Service of the Emergencies Ministry of Russia. Besides, comparison with values defined from video showed the difference from 0.2 to $3.0 \mathrm{~m} / \mathrm{s}$. Calculation by V. V. 
Golubcov, I. I. Herheulidze and M. F. Sribnyj methods provided lower values than the measured one by video material. What is more, those formulas mentioned above produced the similar results.

The closest results were obtained by Kkhann Formula. Nevertheless, this method is based on numerical coefficient and two characteristics such as channel slope and flow depth as the formulas mentioned above.

To sum up, results provided by various methods can both reduce the values of the debris flow velocity (formulas V. V. Golubcov, I. I. Herheulidze and M. F. Sribnyj) and overestimate them (formula of the Academy of the State Fire Service of the Emergencies Ministry of Russia). In case of underestimated values, there is a risk of the defense construction destruction; in other case there are unjustified economic expenditures for the organization of mitigation.

Measurement of debris flow velocity, using video materials from the Internet, is allowing to obtaining mass and statistically significant materials about the values of velocity and flow pattern that are necessary for creations of physical and mathematical models.

As for the model of the transport-shear process, it takes into account debris flow formation processes and such characteristics as the internal angle of friction of the rock, the degree of watering of the soil, the density of the rock, etc. The model at this stage is not fully constructed. Further research and creation of a computer program are required.

\section{Conflicts of Interest}

The authors declare no conflicts of interest regarding the publication of this paper.

\section{References}

[1] Vinogradova, T.A. and Vinogradov, A.Y. (2017) The Experimental Debris Flows in the Chemolgan River Basin. Natural Hazards, 88, 189-198. https://doi.org/10.1007/s11069-017-2853-Z

[2] Cavalli, M., Marchi, L. and Arattano, M. (2013) Protocol for Debris-flow Monitoring. Technical Report, 30. https://www.researchgate.net/publication/278897710

[3] Arattano, M. (2000) Using a Fixed Video Camera to Measure Debris-Flow Surface Velocity, Debris-Flow Hasardz Mitigation: Mechanics, Prediction, and Assessment. Wieczorek \& Naeser, 273-281. https://www.researchgate.net/publication/258453246

[4] Theule, J.I., Crema, S., Marchi, L., Cavalli, M. and Comiti, F. (2018) Exploiting LSPIV to Assess Debris-Flow Velocities in the Field. Natural Hazards and Earth System Sciences, 18, 1-13. https://doi.org/10.5194/nhess-18-1-2018

[5] Li, Y., Liu, J.J., Hu, K.H. and Su, P.C. (2011) Probability Distribution of Measured Debris-Flow Velocity in Jiangjia Gully, Yunnan Province, China. Natural Hazards, 60, 689-701. https://doi.org/10.1007/s11069-011-0033-0 https://www.researchgate.net/publication/257632651

[6] Aulitzky, H. (1989) The Debris Flows of Austria. Bulletin of the International Association of Engineering Geology, 40, 5-13. 
[7] Vinogradov, Yu.B. (1980) Etudes about Mud Streams. Gidrometeoizdat, Leningrad, 144.

[8] OECD (2007) Climate Change in the European Alps Adapting Winter Tourism and Natural Hazards Management: Adapting Winter Tourism and Natural Hazards Management. OECD Publishing, Paris, 136.

[9] Source: Modified from a Document Provided by Munich Re, Geo Risks Research 01/2006 NatCatSERVISE. https://natcatservice.munichre.com/

[10] Hübl, J., Eisl, J. and Tadler, R. (2013) Event Documentation 2012, Annual Review of Events. IAN Report 150, Institute of Mountain Risk Engineering (IAN), University of Natural Resources and Life Sciences, Vienna, Vol. 3, 88.

[11] Kryukov, E.V. and Butenko, V.M. (2013) Dangerous Natural Processes: Manual: Academy of the State Fire Service of the Ministry of Emergency Situations of Russia, 119.

[12] RD 52.30.238-90 Guide to Debris Flow Stations and Hydrographic Batches. Issue 1. Organization and Conduct of Research on Debris Flow.

[13] Golubtcov, V.V. (1969) About the Hydraulic Resistance and a Formula for Calculation of Average Speed of a Current of the Mountain Rivers. Questions of Studying of Mudflows, Works, No. 33, 30-43.

[14] Kazakov, N.A., Gensiorovskii, Yu.V., Kazakova, E.N. and Morozov, G.L. (2013) Mudflow Processes in the Mzymta River Basin (Krasnaya Polyana) and Their Impact on the Territory of Olympic Construction. Geoecology. Engineering Geology, Hydrogeology, Geocryology, No. 6, 516-529. http://www.fegi.ru/elibrary/articles/glaciology/508-kazakov011/file

[15] Vinogradov, Yu. and Vinogradov, T. (2010) Mathematical Modeling in Hydrology, Textbook. Academy, Moscow, 304. 